There was no moon, the wind was south.west and light-the end of the monsoon; and although the sea was, as a matter of fact, breaking here and there, it appeared a calm white sheet, only disturbed by the displacement waves near the ship and a very occasional breaker elsewhere; showing through it were occasional flashes of the ordinary brilliant phosphorescence. It will therefore be seen that the luminosity of the "white sea" was rather less than that of a breaking wave with the same illumination. A bucket of water drawn showed nothing unusual. Samples with and without alcohol were preserved.

A fireball was thrown overboard, and burnt on the surface of the water; this was done in order to see if any fog or mist was present. There was no indication of anything of the kind.

On the port side of the ship is an aperture through which the surplus water from the bath tanks is constantly ejected, slightly warmed. This water, as it fell on to the sea, appeared much blacker than the sea, and floated for a few seconds as alack mass; unfortunately, the same shoot is used for the ashes at times. But the ejected water is quite white by daylight.

The appearance of the sea lasted about an hour, then faded, then brightened again, and was quite bright at daylight, $4.15 \mathrm{a} . \mathrm{m}$.; so that it was seen throughout a distance of nearly fifty miles. A slight recurrence was observed the following night, when the monsoon was blowing more strongly.

At 3 o'clock on the 22nd, in the midst of the "white sea," the latitude was $10^{\circ} 35^{\prime} \mathrm{N}$. and the longitude $63^{\circ} 25^{\prime} \mathrm{E}$.; the temperature of the air was $77^{\circ} \mathrm{F}$., that of the water $77^{\circ} \mathrm{F}$. Specific gravity of the water by ship's instrument No. $13^{1 / 4}$ $=25$.

I shall be glad to hand over the specimens of water to any one interested.

22 Cavendish Square, September 13.

\section{Deep-Sea Dredging, and the Phosphorescence of Living Creatures, at Great Sea Depths.}

May I call attention to this most interesting subject, upon which so little is known, and with reference to the exploration of the bottom of tropical seas ; nothing is lnow'n, though there is here a mine of natural history wealth probably of unexampled magnitude. In that interesting work on "The Depths of the Sea," by Sir Wyville Thomson, published more than twenty years ago, we get a glimpse of a hitherto unworked zoological province, which creates a desire to know more from the richness and beauty revealed, where it would be least expected.

He writes-" "We had a gorgeous display of luminosity, coming down the Sound of Skye, while dredging in 100 fathoms.

"The Pavonarixe came up, resplendent with a pale lilac phosphorescence, like the flame of cyanogen gas-not scintillating, but constant and sufficiently bright to make every portion of a stem distinctly visible, and the stems were a metre long, fringed with hundreds of polyps; and from the number of specimens brought up, we must have passed through a luminous forest of them.

"Among Echinoderms, Ophiacantha spinulosa was one of the prevailing forms, and we were greatly struck with the brilliancy of its phosphorescence. Very young Ophiacantha shone very brightly also.

"At 314 fathoms, some of our hauls were taken late in the erening, and the tangles were sprinkled over with stars of the most brilliant uranium green. The light was not constant, nor continuous all over the stars, but sometines it struck out a line of fire all round the disc; flashing or glowing up to the centre; then that would fade, and the whole five rays of Ophiacantha spinulosa would light up at the ends, and spread the fire inwards.

"At 557 to $5 s_{4}$ fathoms, many of the animals dredged were most brilliantly phosphorescent. In some places, nearly every. thing brought up seemed to emit light, and the very mud itself was perfectly full of luminou; specks. The Pinnatule, Virgularix, and Gorgonie, shone with a lambent white light, so bright that it showed quite distinctly the hour on a watch.

"The light from Ophiacantha spinulosa was a brilliant green, coruscating from the centre of the disc, now along one arm, now along another; and vividly illuminating the whole outline of the star-fish."

From a depth of 567 fathoms, a beautiful scarlet Urchin, Echinus microstoma, was obtained. In the year $1 S_{4} 6$ Keferstein mentions having seen in Stockholm a Crustacean taken from the depth of 1400 fathoms, of a bright colour. In 1869 and 1870 dredging was carried down to 2435 fathoms by H.Mr.'s ship Porcufine, and the fact that there is an abundant and characteristic invertebrate fauna at that great depth was placed beyond question; but the bottom of the deep sea that has been fairly dredged, may still be reckoned by the square yard; while every haul of the dredge, hitherto used, has brought to light new and unfamiliar forms.

In the number of NaTURE for June 30 of this year, there is a most interesting article on deep-sea fishing by means of a trap, an illustration of which is given. These traps are said to have been used at a depth of three thousand fathoms, with complete success. On one occasion a trap that had been lying on the bottom of the Mediterranean, at 700 fathoms depth, for twenty. four hours, brought up I $19 S$ fish, called Simenchely's farasiticus. On another occasion, a new crab, one of the largest ever known, Geryon affinis, was brought up, and there were sixty-four specimens of it. All this shows how much remains to be done in this province of natural history.

Rottingdean.

E. L. J. RIDSDALE.

\section{The Injection of Cocaine as a Remedy for Stings.}

As no one has answered the question asied by Sir J. F. D. Donnelly in your issue of September 8 , will you allow me to say that the hypodermic injection of cocaine, or indeed its use in any form, is never quite free from risk. As with most other drugs there is an element of idiosyncrasy, which sometimes produces unexpected and unpleasant results. I believe these occur more frequently, when the drug is injected, than when it is simply applied to the mucous membrane; and when they do occur, they are very alarming. I know that some dentists have given up the practice of injecting cocaine into the gums before extraction on this account, and having been present once when it was done, I should not consent to it again. What we have to remember with regard to the use of all powerful drugs is this, that a few individuals under all conditions, and nearly all under certain conditions, are specially susceptible to their action, and that we cannot determine i priori either the individuals so predisposed, or the conditions which render susceptible those not specially predisposed. These drugs must therefore be used with caution, and not be regarded as wholly innocuous.

I should say the hypodermic injection of cocaine into the tongue is undesirable, and only to be done if the pain is intense or the swelling such as to threaten life, in which case it would probably be useful. I would add that so far as I know no solutions of cocaine keep well. M.D., Oxox.

\section{THE GEOGRAPHY OF THE UNITED STATES. ${ }^{1}$}

THIS volume completes the description of the North American continent with the exception of Mexico; but, although an excellent account of the United States, it leaves North America itself still undescribed. The general reader, of course, will not miss what he has not been trained to expect; and, if he leaves the conception of geography as a science capable of systematic study out of account, the professed geographer will find much valuable material collected with discrimination and stated clearly and modestly. Indeed, except for an implication on the first page that the United States are in many respects more civilised than Canada, the English reader will find nothing to disturb his equanimity even in the account of the revolutionary war or the feats of the Alabana. Mr. Gannett writes always as a good American, but is ready to recognise the defects of his country when necessary, and careful to buttress all agreeable statements with statistics which more than prove them.

Of the arrangement of the matter it is impossible to speak with the same satisfaction. The chapters do not flow in the natural sequence desirable in a literary work,

1 "Stanford's Compendium of Geography" and Travel" (New Issua). North America. Vol. 1I. "The United States." By. Henry Gannett, Chief tions. Pp. xvi ++55 . (London: Edward Stanford, is 39 .)

No. I 508 , voL. 58$]$ 
nor are the subjects arranged in alphabetical order usual in a book for occasional reference. It is a little of a shock to turn from mineral resources to population, from great cities to the native Indians, and from commerce to Alaska; even although each chapter in itself is excellent reading.

Mr. Gannett was evidently anxious to resist the temptation of enlarging unduly upon his own special subject, and he has in our opinion gone to the opposite extreme, and lost an opportunity of showing how completely the structure of the country determined by its geology dominates the whole geography of the United States. The introductory chapter does contain a good deal of geology in relation to the configuration of the different natural regions, but the connecting links with the other distributions are wanting. It would be better in a book intended primarily for the general English reader to translate the statistics so frecly given into the usual British units of weight and money ; the "short tons" for coal and "long tons" for iron-ore are puzzling, and make

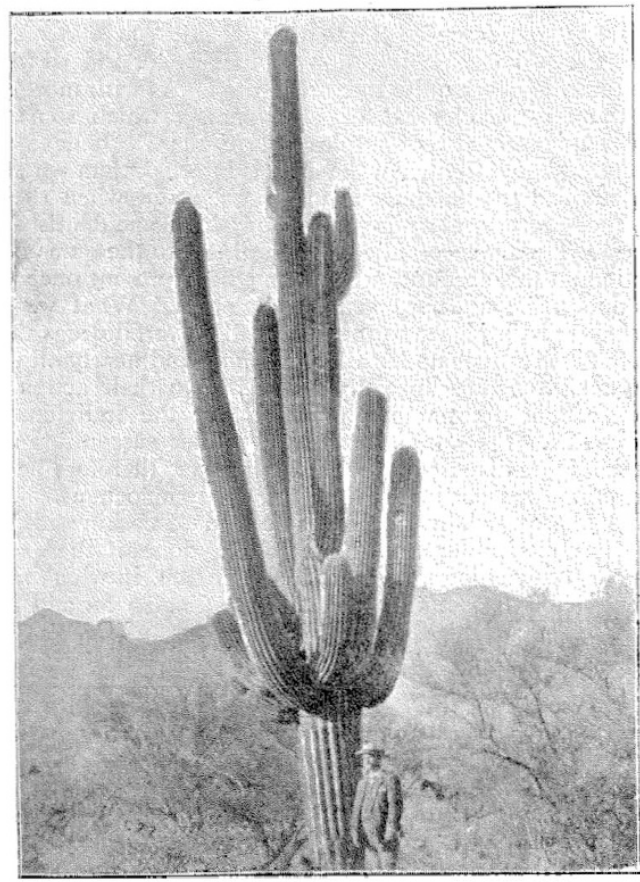

Fig. r,-The Giant Cactus of the Arid Region.

comparison with other countries difficult. Besides, it would greatly assist the clear conception of such statistics if they were expressed in round numbers.

Apart from these possibilities for improvement, the book contains nothing which we cannot heartily praise. The revision of the text is very thorough, and we have not detected a single erratum.

Many of the topics are handled with surprișing freshness, and many interesting points are brought out, such as the changed manner of life of the hardy fishers of the New England coast, who have found an easy and profitable calling as caterers for holiday-makers from the great cities. The author discusses the whole question of American cities, showing how the convenience of the rectangular plan has outweighed asthetic considerations ; and explaining the relative backwardness of the old cities of the east, compared with the new growths of the west, by the vast amount of capital locked up in such archaic conveniences as gas-works and horse or cable cars, while the untrammelled new municipalities can No. I 508 , voL. 58 ] establish electric power-houses at once for all needs. So, too, he shows that no country in the world possesses so many ruined cities as the United States-not only the abodes of the early mound-builders and cliff-dwellers, but ruins of yesterday; mushroum towns that teemed with busy thousands in a year, and were abandoned in a month on the failure of a mine or of a company, leaving only "a history of disappointed hopes, of hardships and struggles,"

The movements of population are well treated, and a map showing the areas where more than Io per cent. of the population are foreign-born, and those where more than Io per cent. of the population are of negro race, displays the interesting fact that the former occupies the whole, north and west, the latter the whole south-east, leaving a narrow belt between the two areas. The number of original statistical and physical maps is one of the most striking and satisfactory features of the book, and the illustrations also are admirably selected. At a time when the United States are entering on a new era

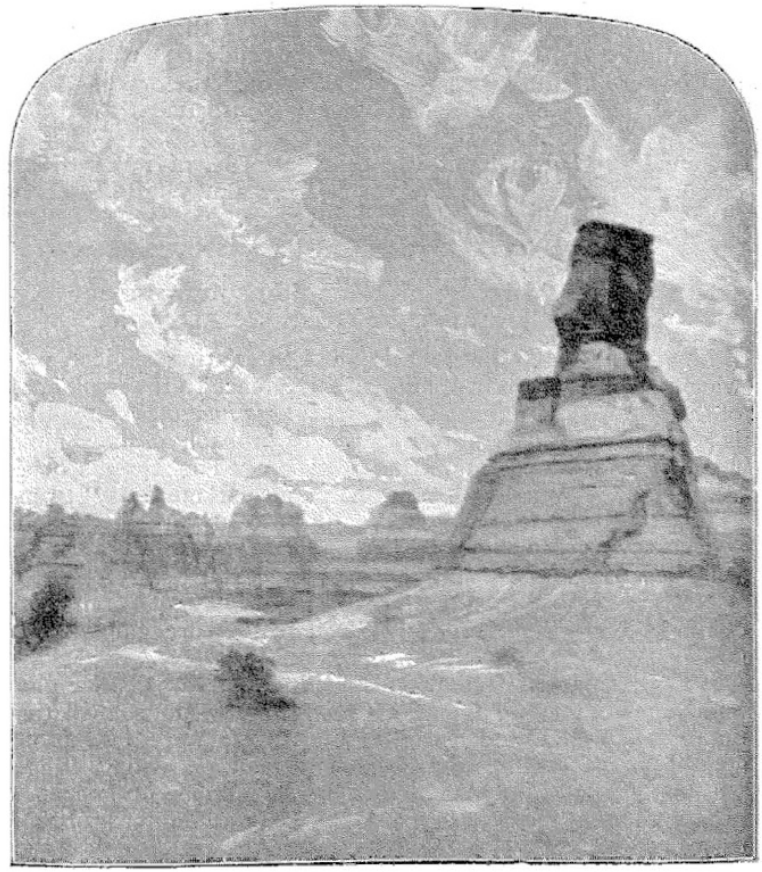

Fig. 2.-Buttes in the Plateau Region.

of their national life, the publication of so accurate and impartial an account of that great country by one of its own citizens is peculiarly appropriate, and deserves a cordial welcome. HUGH ROHERT MILL.

\section{THE BRITISH ASSOCIATION.}

THE concluding meeting of the British Association was held on Wednesday, September 14. Sir William Crookes occupied the chair, and the Mayor of Bristol (Sir R. H. Symes) and the High Sheriff were present, as well as the principal officers and members of the Association. The following report of the mecting is from the Times:-

The proceedings were opened by the announcement that the general committee had been able to pass grants to the amount of $1485 l$. - - an amount which was justified largely by the success of the present meeting.

Sir Norman Lockyer proposed that the thanks of the Association be given to the Mayor, the High Sheriff, the 